\title{
Kajian Pelaksanaan Konsep Kampung Tematik di Kampung Hidroponik Kelurahan Tanjung Mas Kota Semarang
}

\author{
Anindya Putri Tamara1 \\ Departemen Perencanaan Wilayah dan Kota \\ Universitas Diponegoro, Semarang, Indonesia

\section{Mardwi Rahdriawan} \\ Departemen Perencanaan Wilayah dan Kota \\ Universitas Diponegoro, Semarang, Indonesia
}

Artikel Masuk : 25 Januari 2018

Artikel Diterima : 16 Februari 2018

Tersedia Online : 29 April 2018

\begin{abstract}
Abstrak: Permasalahan kemiskinan dan lingkungan permukiman seakan tidak pernah lepas dari kehidupan perkotaan tidak terkecuali Kota Semarang. Salah satu inovasi Pemerintah Kota Semarang dalam mengatasi permasalahan kemiskinan sekaligus mewujudkan penataan pembangunan lingkungan permukiman dilakukan melalui program "GERBANG HEBAT" khususnya dengan pembentukan kampung tematik. Sebagai salah satu program percepatan pembangunan di Kota Semarang, kampung tematik memerlukan perencanaan yang baik untuk dapat mendukung keberlanjutan pelaksanaan kampung tematik. Kampung Hidroponik yang terletak di Kelurahan Tanjung Mas merupakan salah satu kampung tematik yang cukup potensial tetapi memiliki tingkat kemiskinan yang tinggi. Hidroponik yang diangkat sebagai tema kampung nyatanya memiliki tingkat kerumitan tersendiri serta kurang sesuai dengan potensi maupun permasalahan yang terdapat di kawasan pesisir. Penelitian ini bertujuan untuk mengkaji pelaksanaan konsep beserta faktor-faktor yang mempengaruhi tidak berjalannya konsep kampung tematik di Kampung Hidroponik. Pendekatan yang digunakan dalam penelitian ini bersifat kualitatif. Metode penelitian dilakukan dengan teknik analisis data deskriptif kualitatif. Hasil penelitian ini menunjukkan proses pelaksanaan konsep kampung tematik yang terjadi di Kampung Hidroponik, Kelurahan Tanjung Mas tidak menitikberatkan pada pemberdayaan masyarakat. Budidaya hidroponik yang diharapkan dapat meningkatkan kesejahteraan masyarakat perlahan ditinggalkan dan tidak lagi berjalan. Tidak berjalannya pelaksanaan konsep kampung tematik di Kampung Hidroponik disebabkan oleh berbagai faktor di antaranya kurangnya perencanaan konsep kampung, teknis proses pelaksanaan, ketidaksesuaian tema dengan potensi kampung, serta kurangnya pengetahuan dan kesadaran masyarakat.
\end{abstract}

Kata kunci: faktor ketidakberhasilan, hidroponik, kampung tematik, pelaksanaan konsep

Abstract: Poverty and poor settlement problems seem inseparable from the urban living space including in Semarang City. One of the Semarang City Government policy innovations to

\footnotetext{
${ }^{1}$ Korespondensi Penulis: Departemen Perencanaan Wilayah dan Kota, Universitas Diponegoro, Semarang, Indonesia Email: tamaranindya@gmail.com
} 


\section{Kajian Pelaksanaan Konsep Kampung Tematik di Kampung Hidroponik...}

tackle the poverty problems along with urban settlement improvement has been introduced in "GERBANG HEBAT" Program through the formation of kampung tematik (thematic kampong). In line with city development acceleration, thematic kampong needs a comprehensive planning for ensuring its sustainability. Representing a thematic kampong, Hydroponics Kampung in Tanjung Mas Subdistrict is dealing with high poverty level issue. The chosen hydroponics theme has in fact brought forward development complexity in nature against the existing coastal area characteristics. This study aims to examine the implementation of thematic kampong concept as well as the affecting factors towards its ineffectiveness. The research method applies qualitative descriptive data analysis. The results indicate the implementation process of kampong thematic concept in Hydroponics Kampung failed to encourage community empowerment. Hydroponic cultivation to which community welfare improvement sought for has no longer attractive and sustainable. The failure is caused by several factors such as poor kampong improvement planning, poor technical implementation process, the chosen thematic mismatch to the kampong potentials, and the lack of community knowledge and awareness.

Keywords: concept implementation, failure factors, hydroponic, thematic kampong

\section{Pendahuluan}

Pertumbuhan dan perkembangan penduduk yang saat ini terjadi pada kota-kota di negara berkembang seperti Indonesia merupakan imbas dari tingginya arus urbanisasi. Seiring dengan perkembangannya, kawasan perkotaan mengalami berbagai permasalahan yang kompleks. Tingginya laju pertumbuhan penduduk dan permasalahan penyediaan permukiman beserta sarana prasarana pendukungnya serta kemiskinan merupakan permasalahan yang seakan tidak pernah lepas dari kehidupan perkotaan. Penyediaan permukiman beserta sarana dan prasarana pendukungnya hampir selalu tertinggal dibandingkan dengan kecepatan laju pertumbuhan penduduk. Selain itu, meningkatnya tekanan dan kebutuhan penduduk kota terhadap hunian juga turut menyebabkan meningkatnya harga lahan di kawasan perkotaan. Akibatnya, muncul kawasan-kawasan permukiman di perkotaan yang memiliki kepadatan tinggi dan berpotensi menimbulkan berbagai permasalahan. Beberapa permasalahan yang timbul di antaranya adalah keterbatasan pemenuhan sarana dan prasarana pendukung permukiman perkotaan serta lebih lanjut dapat berimbas pada permasalahan perekonomian yaitu kemiskinan.

Kemiskinan merupakan suatu permasalahan global yang sering ditemui di Indonesia, tidak terkecuali di Kota Semarang. Berdasarkan hasil kegiatan Verifikasi dan Identifikasi Warga Miskin Kota Semarang (sesuai dengan Keputusan Walikota Semarang Nomor 050/680/2015 tanggal 13 Juli 2016 tentang Penetapan Database Warga Miskin Kota Semarang), jumlah warga miskin di Kota Semarang tahun 2015 mencapai 114.939 Kepala Keluarga (KK) setara dengan 367.848 jiwa atau sebesar 20,82\% dari 1.767 .086 jiwa dari total penduduk di Kota Semarang. Permasalahan kemiskinan merupakan permasalahan lintas-sektor, lintas-wilayah, dan lintas-generasi, sehingga untuk menanganinya dibutuhkan pendekatan yang terpadu, komprehensif dan berkelanjutan (Rejekiningsih, 2011). Salah satu inovasi Pemerintah Kota Semarang dalam mengatasi permasalahan kemiskinan sekaligus mewujudkan penataan pembangunan kawasan permukiman beserta sarana dan prasarana pendukung yang terdapat di Kota Semarang adalah melalui program "GERBANG HEBAT" khususnya dengan pembentukan kampung tematik.

Kampung tematik mulai dilaksanakan pada pertengahan tahun 2016, memiliki tujuan mengatasi kemiskinan terutama permasalahan pemenuhan kebutuhan dasar, mendorong perekonomian lokal dengan menggali potensi-potensi ekonomi kemasyarakatan sebagai stimulus pembangunan wilayah, serta peningkatan kualitas lingkungan rumah tinggal masyarakat. Sebuah kampung tematik juga diibaratkan sebagai pembangunan yang berorientasi pada pembentukan gagasan, topik yang khas dan unik (Kłoczko-Gajewska, 
2013). Konsep kampung tematik menurut Idziak, Majewski, \& Zmyślony (2015), lebih pada menawarkan masyarakat untuk terlibat proaktif, sehingga tidak hanya berbasis masyarakat akan tetapi juga penciptaan ruang kampung berciri khas yang berkelanjutan oleh masyarakat. Lahir dari gagasan kreatif komunitas maupun masyarakatnya, kampung tematik dapat disebut juga sebuah inovasi sosial (Kloczko-Gajewska, 2014).

Pelaksanaan konsep kampung tematik berdasarkan skema inovasi sosial memiliki tiga tahapan. Tahap pertama merupakan pemetaan problematika yaitu: masyarakat bersama mencari ide/gagasan dalam mengembangkan kampungnya sehingga dapat menciptakan lapangan pekerjaan serta meningkatkan partisipasi masyarakat lokal. Tahap kedua adalah menentukan tema kampung dengan menemukan sekelompok orang yang tertarik untuk dapat bekerja sama dalam menerapkan gagasan atau tema pada kampungnya. Selanjutnya tahap ketiga adalah delineasi dan koordinasi melalui gagasan atau tema yang kemudian dimodifikasi oleh berbagai aktor yang terlibat hingga akhirnya diimplementasikan secara nyata pada wilayahnya. Berdasarkan tiga tahap pelaksanaan konsep kampung tematik dijelaskan pula bahwa kampung tematik dapat berkembang atas kelayakan ide atau tema. Hal ini juga dapat dipengaruhi oleh faktor-faktor seperti karakteristik ekonomi, sosial, adanya potensi lokal yang diangkat, dukungan keuangan dari pihak luar, inisiatif dari tokoh masyarakat, meningkatnya pendapatan, dan inisiatif dari masyarakat (Atkočiūnienè \& Kaminaitè, 2017). Menurut Fosso \& Kahane (2013), suatu konsep pengembangan kawasan seperti kampung tematik dapat mencapai hal yang positif apabila masyarakat dapat berpartisipasi dan melihat dampak positif, potensi peningkatan hingga kemungkinan pendapatan yang dapat dihasilkan. Penelitian yang dilakukan oleh Kloczko-Gajewska (2014) menunjukkan bahwa kampung tematik yang berhasil merupakan kampung yang melibatkan kelompok masyarakat untuk dapat mengimplementasikan tema yang sesuai dengan kampungnya. Sebaliknya, kampung tematik dikatakan tidak berhasil apabila dilihat dari ketidakikutsertaan masyarakat dalam implementasi tema sehingga akhirnya tema itu tidak dapat berjalan hingga ditinggalkan.

Pemerintah Kota Semarang merencanakan kampung tematik dapat terwujud pada setiap kelurahan di Kota Semarang. Pembentukan kampung tematik dilaksanakan bertahap dimulai pada tahun 2016 hingga tahun 2018. Pada tahun 2016 telah dibangun 32 (tiga puluh dua) kampung tematik, kemudian pada tahun 2017 akan bertambah hingga 80 (delapan puluh) titik, sehingga pada akhir tahun 2018 nantinya setiap kelurahan di Kota Semarang akan memiliki kampung tematik yaitu sebanyak 177 (seratus tujuh puluh tujuh) titik. Pelaksanaan konsep kampung tematik pada tahun 2016 ini diharapkan sebagai titik awal perbaikan lingkungan yang sekaligus juga dapat mengangkat potensi sosial ekonomi masyarakat sehingga dapat menanggulangi permasalahan kemiskinan yang terjadi di Kota Semarang.

Salah satu kampung tematik yang cukup potensial tetapi memiliki tingkat kemiskinan tinggi adalah Kampung Hidroponik yang terletak di Kelurahan Tanjung Mas, Kecamatan Semarang Utara, Kota Semarang. Kelurahan Tanjung Mas merupakan kelurahan yang memiliki tingkat kemiskinan tertinggi di Kota Semarang. Kampung Hidroponik yang terbentuk pada pertengahan tahun 2016 merupakan bagian dari perkampungan nelayan Tambak Rejo yang memiliki fungsi utama sebagai pemukiman, tambak dan perdagangan khusus hasil laut (Dimitra \& Yuliastuti, 2012). Letaknya yang berdekatan dengan simpulsimpul penghubung bagi Kota Semarang seperti Pelabuhan Tanjung Mas maupun Stasiun Kereta Api Tawang memberikan kontribusi terhadap tingginya jumlah penduduk di kawasan tersebut. Kawasan pesisir yang dianggap strategis tentunya memiliki berbagai prioritas pengembangan, salah satunya adalah peningkatan kualitas permukiman pesisir sekaligus pengembangan perekonomian lokal kawasan. Hidroponik sebagai salah satu metode penanaman tanaman menggunakan kultur air dimaksudkan untuk dapat meningkatkan produktivitas tanaman sepanjang tahun (Arbi, 2016). Minimnya lahan yang dapat digunakan untuk bercocok tanam serta jenis tanah yang tidak mendukung kegiatan 
pertanian memberikan suatu pemikiran bercocok tanam dengan media selain tanah. Bagi wilayah yang memiliki lahan sempit serta kondisi tanah yang kurang subur, dapat dilakukan pertanian hidroponik karena dalam metode penanaman hidroponik tidak menggunakan tanah sebagai media tanam.

Potensi pengembangan pertanian hidroponik memerlukan sistem berupa lapisan tipis larutan nutrisi yang mengalir melalui bedengan atau talang yang berisikan akar tanaman. Larutan bersirkulasi harus dialirkan secara terus menerus selama 24 jam atau diatur pada waktu-waktu tertentu dengan pengatur waktu (Arbi, 2016). Alat-alat yang dibutuhkan dalam pertanian hidroponik juga beragam dan memiliki harga relatif mahal. Di sisi lain, sebagian besar masyarakat yang menghuni Kampung Hidroponik adalah masyarakat nelayan yang notabene lebih mengesampingkan peningkatan kualitas lingkungan demi pemenuhan kebutuhan pokok mereka (Mussadun \& Nurpratiwi, 2016). Dengan demikian, jika masyarakat nelayan yang hanya mampu untuk memenuhi kebutuhan pokok mereka, maka kebutuhan lain seperti peningkatan kualitas permukiman dan pengembangan pertanian hidroponik akan terbengkalai. Hasil observasi lapangan menunjukkan bahwa 20 paket hidroponik yang terdapat di Kampung Hidroponik Kelurahan Tanjung Mas sudah tidak difungsikan lagi untuk budidaya tanaman.

Mempertimbangkan kondisi tersebut, penelitian ini fokus pada pelaksanaan konsep berikut faktor-faktor yang mempengaruhi tidak berjalannya pelaksanaan konsep kampung tematik. Melalui penelitian ini diharapkan dapat menjadi bahan pembelajaran maupun rekomendasi terkait dengan pengembangan maupun bahan evaluasi bagi pelaksanaan konsep kampung tematik khususnya yang terjadi di Kampung Tematik Hidroponik, Kelurahan Tanjung Mas, Kota Semarang maupun kota-kota lain di masa yang akan datang.

\section{Metode Penelitian}

Penelitian ini pada dasarnya merupakan kajian mengenai pelaksanaan konsep serta faktor-faktor yang mempengaruhi pelaksanaan konsep kampung tematik. Kampung tematik merupakan suatu kawasan di bawah administrasi kelurahan maupun kecamatan yang dapat menunjukkan ciri khas suatu potensi sosial maupun ekonomi wilayah yang diangkat atas dasar kesepakatan masyarakatnya. Pelaksanaan kampung tematik jika dikaitkan dengan skema inovasi sosial dapat memberikan perubahan yang positif menuju proses kolaboratif, serta inisiatif masyarakatnya untuk dapat saling belajar dan melakukan setiap prosesnya secara bersama-sama. Proposisi penelitian ini didasarkan pada teori penanganan kemiskinan dengan pendekatan kewilayahan yang berbasis masyarakat khususnya melalui pelaksanaan konsep kampung tematik. Proposisi penelitian tersebut kemudian digunakan dalam proses pencarian data sebagai input dalam proses analisis yang kemudian masingmasing ditentukan teknik analisis yang akan digunakan.

Pendekatan penelitian yang digunakan pada kajian ini merupakan pendekatan penelitian kualitatif dengan menjelaskan proposisi penelitian yang telah dirumuskan dari berbagai literatur terkait dengan pelaksanaan konsep dan mengkaji faktor-faktor apa saja yang mempengaruhi perkembangan kampung tematik. Pendekatan kualitatif pada dasarnya merupakan suatu pendekatan yang memiliki tujuan untuk memahami fenomena tentang apa yang dialami oleh subjek penelitian seperti perilaku, persepsi, motivasi, dan tindakan secara holistik dengan cara deskripsi dalam bentuk kata-kata dan bahasa pada suatu konteks khusus yang alamiah maupun dengan memanfaatkan berbagai metode alamiah (Moleong, 2009).

Pengumpulan data pada penelitian ini dilakukan melalui pengumpulan data primer dan sekunder. Pengumpulan data primer dilakukan melalui wawancara dan observasi dan pengumpulan data sekunder dilakukan melalui desk study. Wawancara dalam penelitian ini bersifat semi-terstruktur (semi-structured interview) yang dilakukan melalui wawan cara mendalam (in-depth interview). Penentuan sampel yang digunakan dalam penelitian ini 
pada dasarnya adalah non-probability sampling. Penarikan sampel non-probability sampling yang akan digunakan di antaranya adalah purposive sampling dan snowball sampling. Menurut Arikunto (2010), purposive sampling merupakan cara pengambilan sampel berdasarkan subjek bukan didasarkan atas strata, acak atau daerah tetapi didasarkan atas adanya tujuan tertentu. Adapun snowball sampling merupakan teknik pengambilan sampel yang bermula sedikit selanjutnya berkembang menjadi lebih banyak selaras dengan perkembangan pemenuhan informasi hingga data atau informasi yang didapat mengalami kejenuhan (Sugiyono, 2015).

Pertimbangan dalam pemilihan sampel atau penentuan responden kunci adalah sampel atau responden kunci tersebut merupakan orang-orang yang mengetahui dan terlibat dalam pembentukan kampung tematik khususnya yang terdapat di Kampung Hidroponik, Kelurahan Tanjung Mas. Pemilihan responden kunci dalam penelitian ini juga didasarkan pada dokumen Monitoring dan Evaluasi Kampung Tematik Kota Semarang Tahun 2016 yang diterbitkan oleh Bappeda Kota Semarang. Dokumen tersebut menginformasikan mengenai Organisasi Perangkat Daerah (OPD) yang terlibat dalam pembentukan Kampung Tematik Hidroponik di Kelurahan Tanjung Mas.

Setelah melakukan penentuan sampel, langkah selanjutnya adalah melakukan pengambilan data untuk analisis. Analisis data pada penelitian kualitatif dapat dilakukan sejak sebelum memasuki lapangan, pada saat di lapangan, maupun setelah selesai di lapangan. Hubungan antara tahapan satu dengan tahapan lainnya sesuai dengan proses analisis data dalam penelitian kualitatif berlangsung dari awal hingga pada akhir penelitian (Mursidik, Samsiyah, \& Rudyanto, 2015). Kegiatan analisis pada penelitian ini juga berlangsung secara terus-menerus selama penelitian berlangsung. Berikut merupakan tahapan analisis yang dilakukan dalam penelitian ini, yaitu:

a. Identifikasi pelaksanaan konsep kampung tematik

Identifikasi pelaksanaan konsep kampung tematik didasarkan pada tata cara pelaksanaan yang telah dirumuskan oleh Bappeda Kota Semarang serta skema inovasi sosial yang terdapat pada kampung tematik. Selain itu, melalui identifikasi pelaksanaan konsep kampung tematik maka dapat diketahui mekanisme atau tata cara pelaksanaan konsep kampung tematik kemudian siapa saja aktor yang terlibat, kelompok masyarakat yang terbentuk untuk mendukung kampung tematik serta peran masing-masing aktor dalam pelaksanaan konsep kampung tematik.

b. Identifikasi karakteristik fisik dan masyarakat

Karakter fisik dan masyarakat merupakan suatu hal dasar yang perlu diketahui dalam suatu penelitian. Karakter fisik dilihat dari potensi fisik wilayah yang terdapat di Kelurahan Tanjung Mas, sedangkan karakter masyarakat dilihat dari aspek sosial maupun ekonomi masyarakat.

c. Analisa kelayakan tema kampung tematik

Analisis ini bertujuan untuk mengetahui implementasi tema yang diangkat pada kampung tematik apakah sudah dapat dikatakan layak atau belum dengan melihat pada tiga aspek yaitu aspek sosial, ekonomi dan infrastruktur. Kelayakan tema dalam penelitian ini akan dianalisis sesuai dengan kisi-kisi penelitan yang telah ditetapkan.

\section{Hasil Pembahasan}

\section{Identifikasi Pelaksanaan Konsep Kampung Hidroponik}

Kampung Tematik merupakan salah satu bagian dari strategi penanggulangan kemiskinan dan peningkatan kualitas lingkungan permukiman yang terpadu di Kota Semarang. Pelaksanaan kampung tematik mengubah skema penanggulangan permasalahan kemiskinan maupun lingkungan permukiman yang pada awalnya lebih menitikberatkan pada pemberian bantuan hingga pada pelibatan aktif dari berbagai 
pemangku kepentingan serta masyarakat. Tujuan dari pelaksanaan kampung tematik adalah untuk mengoptimalkan seluruh potensi lokal yang ada di Kota Semarang dalam melalukan percepatan penanggulangan kemiskinan sehingga dapat tercapai secara efisien dan efektif. Dukungan dari berbagai pemangku kepentingan maupun masyarakat serta komunikasi dan koordinasi yang baik diperlukan dalam pelaksanaan konsep kampung tematik. Pemerintah Kota Semarang kemudian mencoba untuk mensinergikan berbagai pemangku kepentingan seperti OPD, perguruan tinggi negeri (PTN) dan perguruan tinggi swasta (PTS), lembaga swadaya masyarakat (LSM), perbankan, Badan Usaha Milik Neg ara (BUMN), Badan Usaha Milik Daerah (BUMD), tokoh masyarakat, media massa serta pihak swasta/pengusaha untuk dapat turut mendukung pelaksanaan kampung tematik. Skema kelembagaan dalam pelaksanaan kampung tematik Kota Semarang dapat dilihat pada Gambar 1.

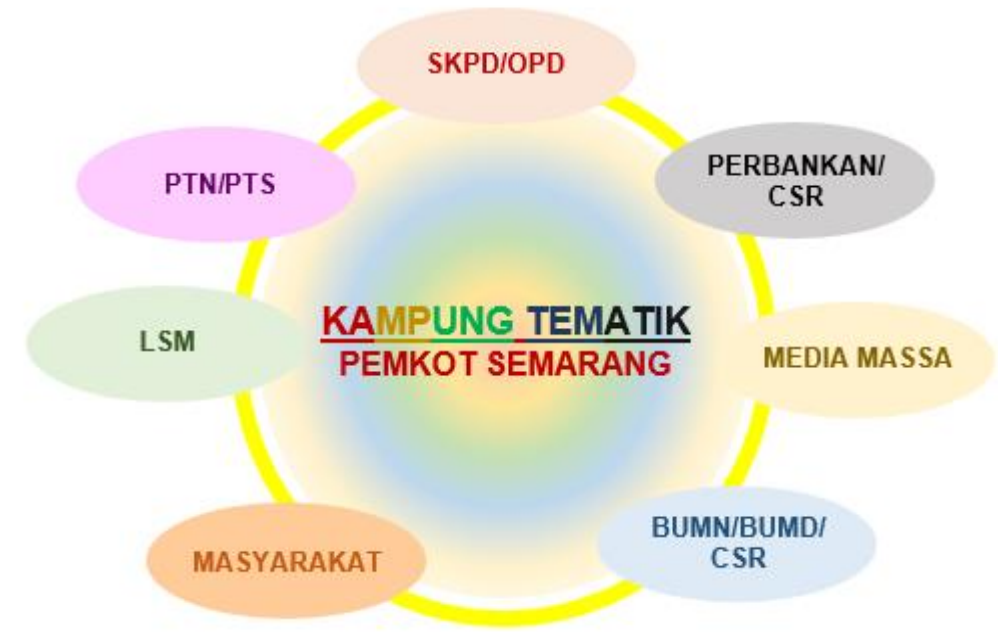

Sumber: Hasil Analisis, 2017

\section{Gambar 1. Kelembagaan dalam Pelaksanaan Kampung Tematik Kota Semarang}

Pemerintah Kota Semarang melalui Petunjuk Teknis Pembentukan Kampung Tematik Kota Semarang Tahun 2017, menjelaskan bahwa pelaksanaan kampung tematik diawali dengan pemetaan potensi (sosial, ekonomi, dan infrastruktur). Pemetaan potensi dilakukan dengan scoring untuk skala prioritas sehingga kemudian dapat ditarik gambaran mengenai tema yang diangkat pada suatu kampung. Setelah pemetaan potensi, tahapan selanjutnya adalah penentuan tema kampung. Tahapan penentuan tema kampung berdasarkan petunjuk teknis pelaksanaan kampung tematik yang terbit pada tahun 2017 dilakukan dengan melibatkan berbagai aktor, seperti perwakilan kelurahan dan masyarakat yang terdiri dari Lembaga Pemberdayaan Masyarakat Kelurahan (LPMK), Badan Keswadayaan Masyarakat (BKM), Tokoh Masyarakat, Pembinaan Kesejahteraan Keluarga (PKK), Karang Taruna). Pelibatan berbagai aktor dalam penentuan tema kampung dilakukan dalam suatu forum sehingga usulan tema kampung dapat dibahas dan disepakati secara bersama-sama. Penentuan tema kampung merupakan salah satu hal yang penting dalam pelaksanaan kampung tematik. Pentingnya penentuan tema yang melibatkan berbagai aktor khususnya masyarakat bertujuan untuk dapat menjaring potensi lokal dari suatu wilayah baik dari aspek sosial maupun ekonomi sehingga potensi tersebut dapat menjadi tema kampung yang nantinya dapat memberikan pengaruh pada pengembangan ekonomi lokal serta upaya penyelesaian yang dapat menghasilkan solusi permasalahan 
lingkungan permukiman (Kloczko-Gajewska, 2014). Tahapan yang dilakukan setelah penentuan tema adalah desain tema. Tahapan desain tema merupakan penggambaran kondisi yang akan dicapai. Selanjutnya, penyusunan program/kegiatan dalam kampung tematik. Program atau kegiatan kampung tematik disusun berdasarkan kriteria sosial, ekonomi dan infrastruktur dengan tetap memperhatikan tema utama. Terakhir adalah pelaporan dan evaluasi yang dilaksanakan maksimal satu bulan setelah pekerjaan pembangunan kampung tematik selesai. Proses pelaksanaan kampung tematik sebagaimana yang dijelaskan dalam Petunjuk Teknis Pembentukan Kampung Tematik Kota Semarang Tahun 2017 dapat dilihat pada Gambar 2.

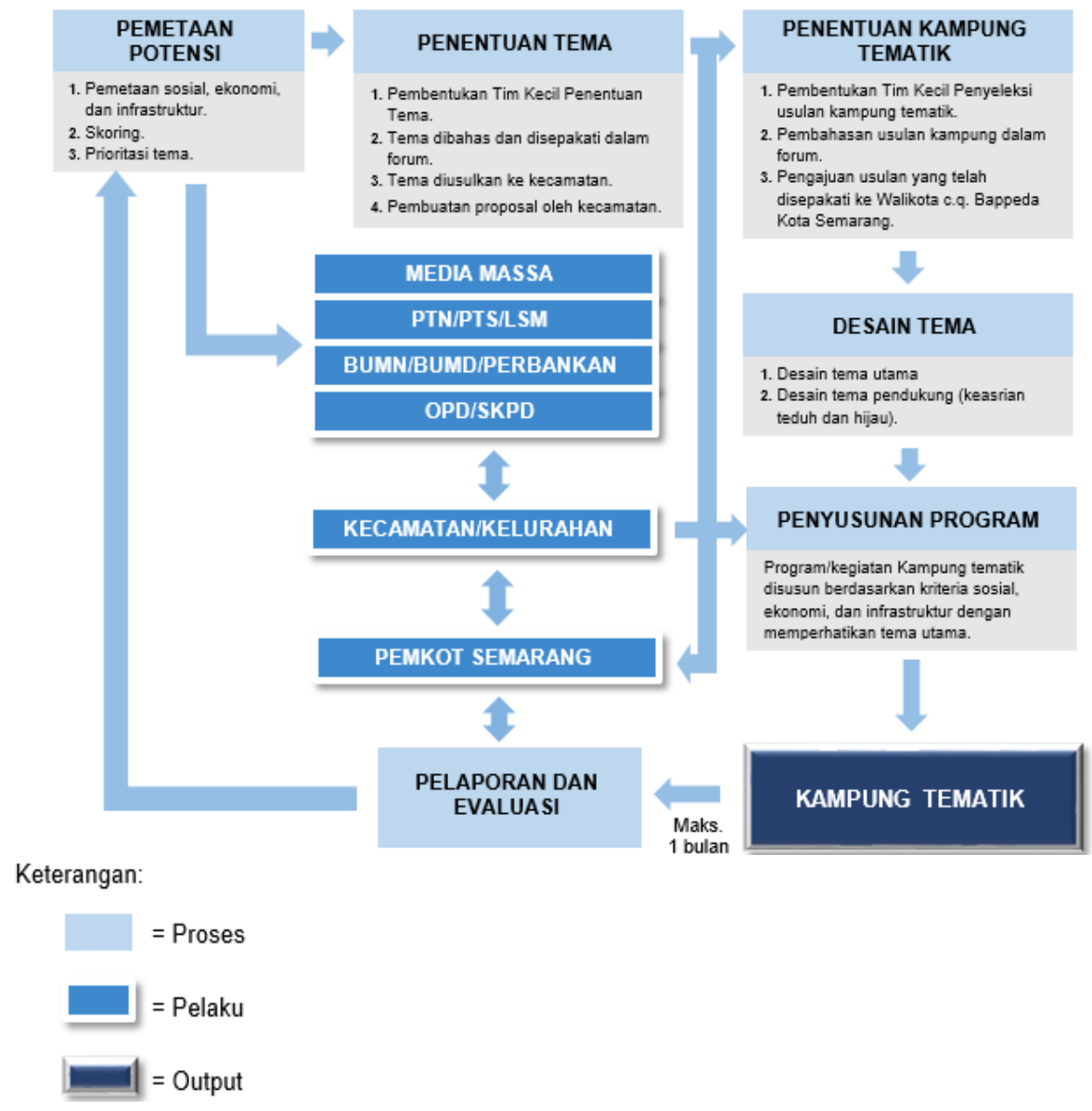

Sumber: Hasil Analisis, 2017

\section{Gambar 2. Proses Pelaksanaan Kampung Tematik berdasarkan PetunjukTeknis Bappeda 2017}

Namun pada kenyataannya, proses pelaksanaan kampung tematik khususnya yang terjadi di Kampung Hidroponik, Kelurahan Tanjung Mas tidak berjalan sesuai dengan Tata Cara Pelaksanaan Kampung Tematik yang terdapat dalam Petunjuk Teknis Pembentukan Kampung Tematik Kota Semarang Tahun 2017. Hal tersebut terjadi salah satunya karena pada kampung tematik tahun 2016 belum terdapat petunjuk teknis pelaksanaan kampung tematik. Dalam hal ini pihak pemerintah yaitu Bappeda Kota Semarang selaku penyelenggara kegiatan hanya memberikan kisi-kisi pelaksanaan konsep kampung tematik. Pada saat itu, hal utama yang ditekankan mengenai kampung tematik adalah setiap kelurahan mengangkat potensi lokal baik dari segi sosial maupun ekonomi melalui kesepakatan masyarakatnya. 
Seperti yang telah diungkapkan oleh pihak Bappeda, pelaksanaan kampung tematik yang terjadi di Kampung Hidroponik, Kelurahan Tanjung Mas juga menggunakan pola pendekatan top-down. Pemerintah, perencana, pakar, maupun teknokrat pada pola pendekatan top-down dianggap sebagai pihak yang memiliki seluruh pengetahuan, informasi, maupun akses yang dibutuhkan untuk dapat mencapai tujuan dari pembangunan. Namun, pola pendekatan top-down seringkali dianggap kaku dan kurang didasarkan pada pertimbangan yang berakar pada kebutuhan masyarakat lokal (Suradisastra, 2008). Pemilihan hidroponik sebagai tema kampung tematik di Kelurahan Tanjung Mas dilakukan oleh pihak kecamatan juga kelurahan tanpa melibatkan masyarakat pada penentuan tema kampung. Tema kampung secara langsung ditetapkan baru kemudian disosialisasikan kepada masyarakat. Berkaitan dengan kondisi tersebut Suradisastra (2008) menyebutkan bahwa masyarakat hendaknya terlibat dalam upaya penanggulangan kemiskinan dengan bantuan dan tuntunan pelaksana kebijakan. Adanya keterlibatan masyarakat dalam proses penentuan tema maupun implementasi dapat berimbas pada hasil program/kegiatan yang lebih responsif. Namun, pola maupun pendekatan pemberdayaan masyarakat dengan menitikberatkan pada pengembangan potensi lokal yang didorong sebagai landasan pelaksanaan kampung tematik digantikan seluruhnya dengan pola dan pendekatan yang disesuaikan dengan waktu serta tuntutan kebutuhan masyarakat. Detail proses pelaksanaan konsep kampung tematik di Kampung Hidroponik, Kelurahan Tanjung Mas dapat dilihat pada Gambar 3.

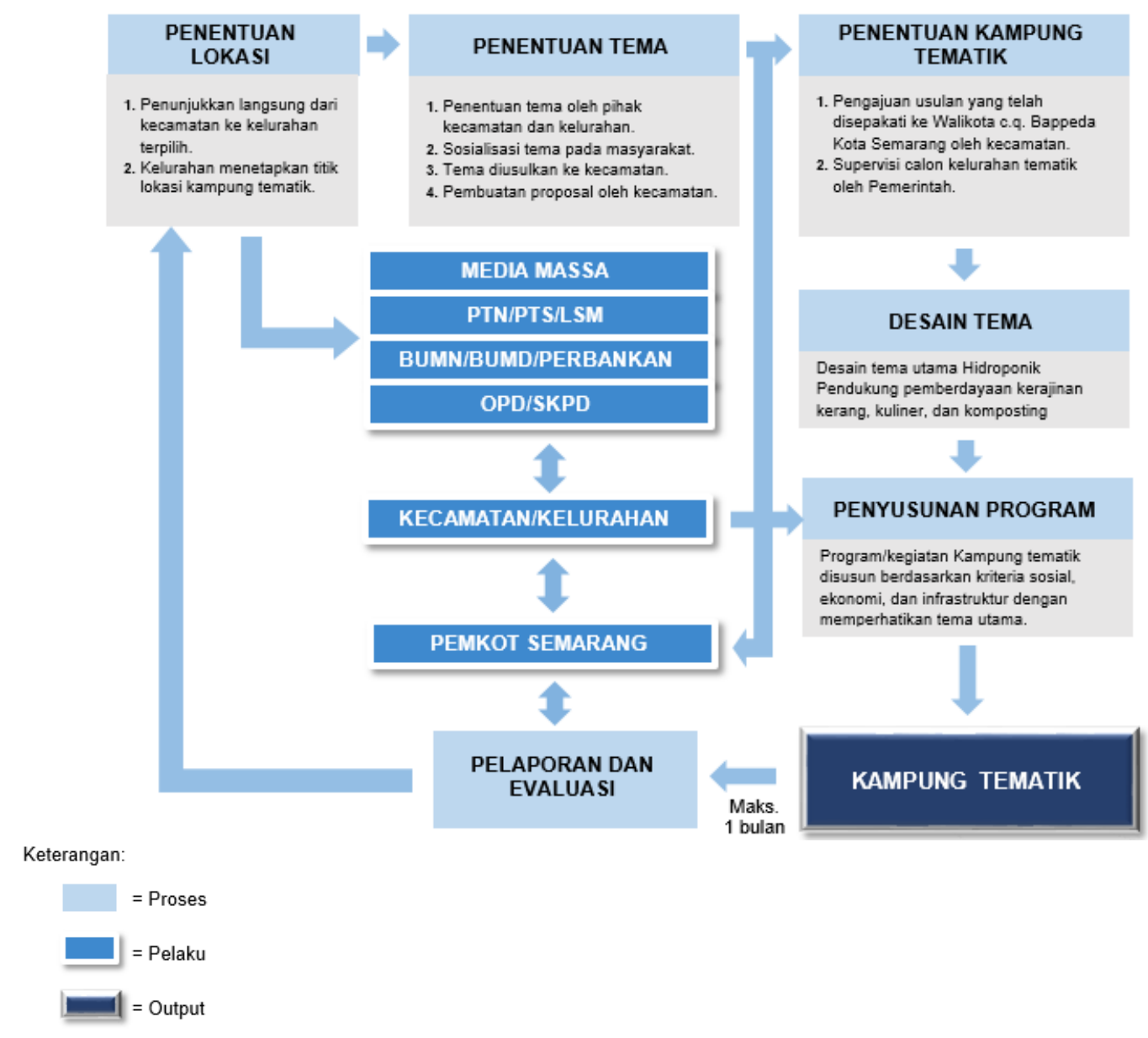

Sumber: Hasil Analisis, 2017 
Kegiatan pelaksanaan Kampung Hidroponik yang awalnya diharapkan dapat menjadi suatu kegiatan yang berkelanjutan nyatanya hanya dapat bertahan kurang lebih lima bulan saja. Kampung Hidropnik yang pada awal pelaksanaannya mendapatkan 20 paket hidroponik untuk dikelola oleh masyarakat kini sudah tidak lagi beroperasi sebagaimana mestinya. Meskipun pada pelaksanaannya terdapat kegiatan sosialisasi maupun pelatihan mengenai budidaya hidroponik, nyatanya hal tersebut tidak berpengaruh pada peningkatan pengetahuan maupun keinginan masyarakat untuk melakukan budidaya hidroponik. Saat ini, kondisi budidaya hidroponik yang terdapat di RW 16, Kelurahan Tanjung Mas seluruhnya sudah tidak beroperasi lagi, bahkan 7 dari 20 paket hidroponik yang diberikan oleh pemerintah mengalami kerusakan dan tidak dapat dipergunakan kembali. Tidak beroperasinya budidaya hidroponik di Kampung Hidroponik, Kelurahan Tanjung Mas mulai terlihat pada awal tahun 2017 setelah berakhirnya kegiatan kampung tematik.

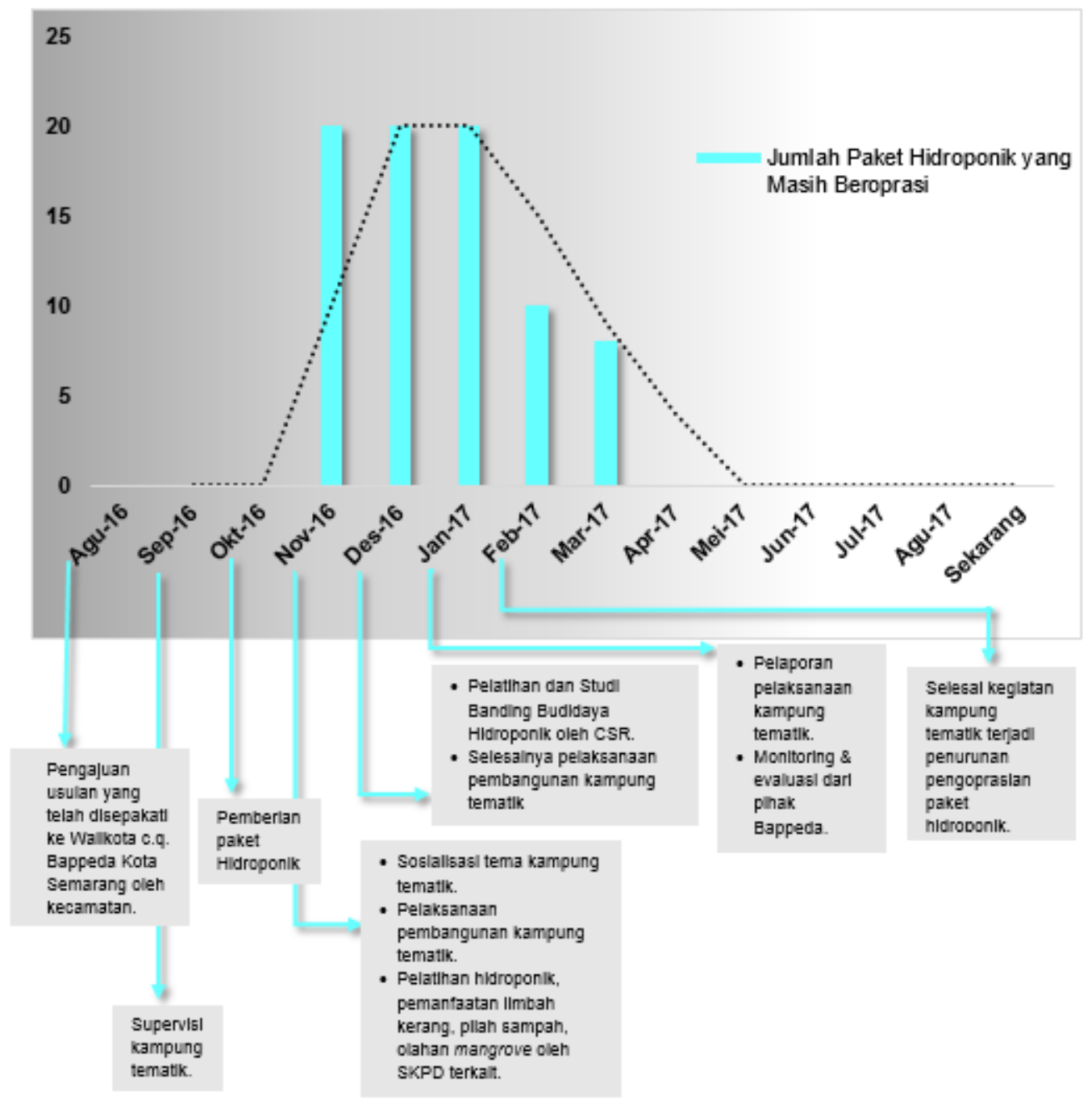

Sumber: Hasil Analisis, 2017

Gambar 4. Pelaksanaan Kampung Hidroponik 


\section{Identifikasi Karakteristik Fisik dan Masyarakat Kampung Hidroponik}

\section{Karakter Fisik Kampung Hidroponik Kelurahan Tanjung Mas}

Kampung Hidroponik yang terletak di sebelah utara Kota Semarang mengakibatkan wilayah tersebut memiliki kondisi lingkungan fisik yang berbeda dibanding dengan wilay ah lainnya di Kota Semarang. Pada dasarnya wilayah pesisir sangat identik dengan tanah yang kurang subur, kondisi air baku yang payau, serta suhu udara yang panas. Menurut Gernowo, Kusworo, \& Arifin (2013), pada sebelah utara Kota Semarang menggambarkan adanya urban heat island khususnya pada lahan terbuka, permukiman maupun industri dan hal tersebut tentunya berimbas pada tingginya suhu udara. Jenis tanah aluvial yang terdapat di wilayah ini juga memiliki tingkat produktivitas pertanian yang rendah sehingga tidak dapat mendukung kegiatan pertanian.

Kelurahan Tanjung Mas yang mengangkat hidroponik sebagai tema kampungnya pada dasarnya memiliki tujuan untuk mengembangkan pertanian tanpa menggunakan tanah sebagai media tanam, mengingat kondisi tanah di kawasan ini merupakan tanah aluvial dengan tingkat kesuburan yang relatif rendah. Pada pelaksanaan Kampung Hidroponik, Pemerintah Kota Semarang memberikan dukungan dana sebesar 200 juta rupiah yang sebagian besar dialokasikan untuk penyediaan media tanam maupun peralatan budidaya hidroponik. Media maupun peralatan yang diperlukan untuk melakukan budidaya hidroponik diperlukan untuk menunjang tanaman agar dapat tumbuh secara optimal.

Budidaya tanaman menggunakan metode hidroponik pada dasarnya memang tidak memerlukan lahan yang luas dalam pelaksanaannya, akan tetapi dalam pelaksanaannya terdapat berbagai tantangan bagi masyarakat yang melakukannya baik dari sejak pembibitan hingga sampai ke pemanenan. Tantangan dalam budidaya hidroponik terjadi terutama apabila budidaya dilakukan secara terbuka, tanpa atap atau tidak menggunakan greenhouse seperti yang terdapat di Kampung Hidroponik, Kelurahan Tanjung Mas. Hal tersebut berarti masyarakat yang melakukan budidaya hidroponik harus dapat menghadapi berbagai kondisi cuaca baik panas maupun hujan serta beberapa kendala lain yang dapat merusak kualitas sayuran.

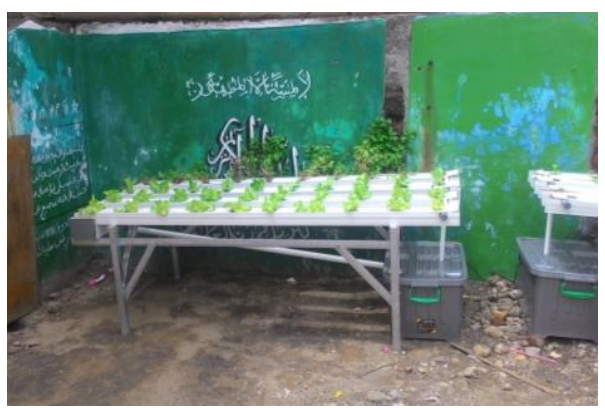

(a)

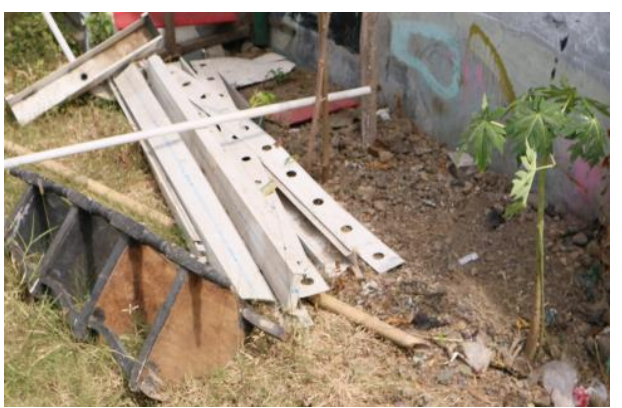

(b)

Sumber: Hasil Observasi, 2017

\section{Gambar 5. (a) Penempatan Tanaman Hidroponik pada Awal Pelaksanaan Kampung Tematik 2016; (b) Kondisi Tanaman Hidroponik Pasca Pelaksanaan Kampung Tematik Tahun 2016}

Menurut Heriwibowo \& Budiana (2014), karakteristik dari budidaya tanaman deng an menggunakan hidroponik yang cenderung lebih rumit dibandingkan dengan menanam menggunakan media tanah tentunya berdampak bagi keberhasilan dalam pelaksanaan kampung tematik di Kelurahan Tanjung Mas. Suhu, kelembapan, cahaya, sirkulasi udara, aspek lokasi budidaya, sumber air yang ada di lokasi budidaya, produk yang mutakhir, investasi yang tinggi, serta keahlian khusus merupakan beberapa hal yang perlu 
diperhatikan sebelum melakukan budidaya tanaman menggunakan metode hidroponik. Akan tetapi dalam budidaya hidroponik yang terjadi di Kelurahan Tanjung Mas seakan luput dari penglihatan baik masyarakat maupun pemerintah. Penerapan budidaya hidroponik yang mulanya diharapkan dapat mengatasi permasalahan keterbatasan lahan pertanian dan meningkatkan kualitas lingkungan serta membantu menambah penghasilan masyarakat sekitar Kampung Hidroponik di Kelurahan Tanjung Mas nyatanya tidak dapat terlaksana sesuai dengan harapan.

2. Karakter Masyarakat Kampung Hidroponik Kelurahan Tanjung Mas

Pelaksanaan konsep kampung tematik yang terjadi di Kampung Hidroponik pada awalnya disambut hangat oleh masyarakat. Hal tersebut terlihat dari antusiasme masyarakat dalam penerimaan 20 paket hidroponik oleh Pemerintah Kota Semarang. Penerima 20 paket hidroponik yang terdapat di Kampung Hidroponik, Kelurahan Tanjung Mas tidak ditentukan oleh masyarakat namun langsung ditunjuk oleh pihak kelurahan atas pertimbangan masukan dari Ketua RW 16. Menurut Ketua RW 16, pertimbangan penentuan penerima paket hidroponik adalah letak hunian yang berdekatan dengan jalan utama. Paket hidroponik diletakkan oleh pihak kecamatan pada tiap RT di RW 16 Kelurahan Tanjung Mas sebagai lokasi pelaksanaan Kampung Hidroponik dengan tidak mempertimbangkan jumlah pemberian paket. Beberapa paket hidroponik juga diletakkan pada fasilitas umum maupun kelompok masyarakat seperti PAUD dan Gazebo Kelompok Tani "CAMAR" atau "Cinta Alam Mangrove Asri dan Rimbun". Menurut Lurah Tanjung Mas, pemilihan lokasi peletakan hidroponik di PAUD dipilih karena pada lokasi tersebut berdekatan dengan jalan utama Kelurahan Tanjung Mas. Peletakan di Gazebo Kelompok Tani "Camar" dilakukan untuk memberikan stimulus awal dalam budidaya tanaman menggunakan media hidroponik bagi kelompok tani yang sudah dapat mengembangkan mangrove. Daftar penerima paket hidroponik di Kampung Hidroponik dapat dilihat pada Tabel 1.

Tabel 1. Penerima Paket Hidroponik pada Pelaksanaan Kampung Hidroponik

\begin{tabular}{clcc}
\hline No & \multicolumn{1}{c}{ Penerima } & RT/RW & Jumlah Paket Hidroponik \\
\hline 1. & Arifin & $01 / 16$ & 2 \\
2. & Puji & $01 / 16$ & 1 \\
3. & Ningrum & $01 / 16$ & 1 \\
4. & Agus & $01 / 16$ & 3 \\
5. & Joko & $01 / 16$ & 2 \\
6. & PAUD PS & $02 / 16$ & 2 \\
7. & Slamet & $02 / 16$ & 2 \\
8. & Tumirah & $02 / 16$ & 1 \\
9. & Suwito & $03 / 16$ & 2 \\
10. & Kelompok "CAMAR" & $04 / 16$ & 2 \\
Jumlah & & 20 \\
\hline
\end{tabular}

Sumber: Hasil Observasi, 2017

Selain pemberian paket hidroponik, pihak Kecamatan Semarang Utara juga mengadakan sosialisasi maupun pelatihan untuk dapat meningkatkan kapasitas dan pengetahuan masyarakat. Antusiasme masyarakat dalam pelaksanaan kampung tematik ini juga terlihat dari keikutsertaan masyarakat dalam kegiatan sosialisasi maupun pelatihan yang diadakan oleh pihak kecamatan maupun kelurahan. Sifat antusias masyarakat ini sebenarnya sudah dimiliki masyarakat RW 16 Kelurahan Tanjung Mas sejak sebelum pelaksanaan Kampung Hidroponik. Hal ini ditunjukkan dengan adanya Kelompok Tani "CAMAR" yang masih tetap eksis dalam meningkatkan kualitas lingkungan dengan budidaya mangrove maupun cemara laut. Sosialisasi maupun pelatihan yang dilakukan oleh pihak kelurahan maupun kecamatan tidak hanya terpaku pada hidroponik saja akan 
tetapi juga pengembangan potensi lokal yang terdapat di Kampung Hidroponik, Kelurahan Tanjung Mas. Beberapa sosialisasi maupun pelatihan yang telah diadakan pada pelaksanaan kegiatan Kampung Hidroponik antara lain dapat dilihat pada Tabel 2.

Tabel 2. Sosialisasi dan Pelatihan pada Pelaksanaan Kampung Hidroponik

\begin{tabular}{|c|c|c|c|c|c|c|}
\hline \multirow{2}{*}{ No. } & \multirow{2}{*}{ Pelatihan } & \multirow{2}{*}{$\begin{array}{c}\text { Tanggal } \\
\text { Pelaksanaan }\end{array}$} & \multicolumn{4}{|c|}{ Jumlah Peserta } \\
\hline & & & $\mathbf{P}$ & $\mathbf{A}$ & $\mathbf{C}$ & M \\
\hline 1. & Sosialisasi Kampung Tematik & 20 November 2016 & 11 & 4 & 2 & 118 \\
\hline 2. & $\begin{array}{l}\text { Pelatihan Membuat Souvenir dari Limbah } \\
\text { Kerang Hijau dan Hasil Laut Lainnya }\end{array}$ & 21 November 2016 & 10 & 2 & - & 46 \\
\hline 3. & Pelatihan Pilah Sampah dan Kompos & 23 November 2016 & 5 & 7 & - & 46 \\
\hline 4. & $\begin{array}{l}\text { Pelatihan Pemanfaatan Tanaman Mangrove } \\
\text { untuk Bahan Makanan }\end{array}$ & 28 November 2016 & 3 & 2 & - & 55 \\
\hline 5. & Pelatihan Budidaya Tanaman Hidroponik & 30 November 2016 & 1 & 8 & - & 21 \\
\hline 6. & $\begin{array}{l}\text { Studi Banding untuk Meningkatkan Ketrampilan } \\
\text { dan Kemandirian Mas yarakat dalam Kegiatan } \\
\text { Hidroponik dan Budidaya Sayuran Pekarangan } \\
\text { oleh Indonesia Power }\end{array}$ & 22 Desember 2016 & 6 & 7 & 1 & 21 \\
\hline
\end{tabular}

Sumber: Hasil Observasi, 2017

Namun, seiring berjalannya waktu antusiasme masyarakat mulai hilang. Penerima hidroponik yang tadinya bersemangat melakukan budidaya hidroponik kemudian perlahan berhenti melakukan budidaya. Penerima paket hidroponik mengungkapkan bahwa terdapat berbagai kendala membuat mereka akhirnya tidak lagi melakukan budidaya hidroponik. Beberapa di antaranya sangat berkaitan dengan karakteristik masyarakat yang terdapat di Kelurahan Tanjung Mas yang mayoritas penduduknya merupakan masyarakat miskin yang lebih mengesampingkan kebutuhan-kebutuhan yang bukan primer seperti peningkatan kualitas hidup mereka salah satunya budidaya hidroponik (Mussadun \& Nurpratiwi, 2016). Budidaya hidroponik merupakan budidaya tanaman dengan menggunakan air yang mengalir sehingga sistem budidaya hidroponik tidak dapat terlepas dari sumber tenaga listrik sebagai penggerak dari pengairan. Hal tersebut menjadikan suatu kendala tersendiri mengingat pembiayaan listrik untuk budidaya hidroponik berbanding terbalik dengan kondisi masyarakat Kampung Hidroponik yang mayoritas merupakan masyarakat miskin. Karakteristik budidaya hidroponik yang relatif lebih susah dibandingkan dengan budidaya tanaman menggunakan media tanah tidak dibarengi dengan pengetahuan masyarakat akan pengelolaan hidroponik secara baik dan benar.

\section{Analisis Kelayakan Tema Kampung Hidroponik}

Penggambaran potensi sosial maupun ekonomi masyarakat melalui suatu tema yang diangkat dan dikembangkan untuk pembangunan sehingga dapat memberikan makna tertentu dalam kehidupan masyarakat di lingkungan tempat tinggalnya merupakan ciri dari kampung tematik. Tema merupakan suatu hal yang penting diperhatikan dalam pelaksanaan kampung tematik. Bappeda melalui Petunjuk Teknis Kampung Tematik Tahun 2017 kemudian menentukan indikator-indikator yang dapat digunakan untuk menentukan kelayakan tema pada kampung tematik. Indikator-indikator sosial, ekonomi, dan infrastruktur.

Aspek sosial merupakan salah satu indikator yang digunakan untuk menentukan kelayakan tema pada kampung tematik. Poin-poin yang perlu diperhatikan pada aspek sosial di antaranya adalah wilayah/kampung yang akan dijadikan kampung tematik 
mengutamakan kemiskinan yang dapat dikembangkan. Hal tersebut sesuai dengan Kampung Hidroponik, Kelurahan Tanjung Mas yang merupakan kelurahan yang memiliki tingkat kemiskinan tertinggi di Kota Semarang. Selanjutnya, terdapat poin kemauan serta pemberdayaan masyarakat untuk mengangkat dan memajukan wilayah/kampungnya. Poin yang terakhir adalah terdapatnya permasalahan sosial yang mendesak untuk ditangani. Kampung Hidroponik merupakan salah satu bagian dari perkampungan nelayan di Kota Semarang yang memiliki berbagai permasalahan di antaranya penyakit sosial maupun kerusakan lingkungan (Mussadun \& Nurpratiwi, 2016). Untuk menangani permasalahan tersebut pemerintah maupun berbagai lembaga nonpemerintah sering melakukan pemberdayaan di Kelurahan Tanjung Mas. Namun, sasaran berbagai program pemberdayaan masyarakat sekitar Kelurahan Tanjung Mas yang mayoritas bermatapencaharian sebagai nelayan seringkali bersikap apatis dan tidak memiliki keinginan untuk meningkatkan ketrampilannya (Indarti, 2015). Hal tersebut dapat berimbas pada tidak adanya peningkatan ketrampilan maupun kualitas kehidupan masyarakat di wilayah pesisir Kota Semarang khususnya Kampung Hidroponik.

Indikator lain yang menjadi tolok ukur dalam menentukan kelayakan tema pada kampung tematik adalah ekonomi. Terdapat tiga poin yang dapat menentukan kelayakan kampung jika ditinjau dari aspek ekonomi. Poin pertama adalah adanya potensi lokal baik sumber daya manusia maupun sumber daya alam yang dapat diangkat sebagai sumber penggerak perekonomian lokal. Namun, potensi lokal yang diangkat oleh Kelurahan Tanjung Mas bukan merupakan potensi lokal yang benar-benar dimiliki wilayah tersebut. Hidroponik merupakan hal yang baru bagi masyarakat di Kelurahan Tanjung Mas terlebih lagi bagi masyarakat nelayan. Pekerjaan nelayan yang pada dasarnya adalah mengambil dan menangkap ikan sangat berkebalikan dengan kegiatan budidaya hidroponik. Produkproduk lokal yang terdapat di Kelurahan Tanjung Mas juga tidak memiliki keterkaitan dengan budidaya hidroponik. Meskipun, Kampung Hidroponik memiliki kelompok masyarakat yang aktif dalam kegiatan pertanian namun dalam hal ini hidroponik merupakan suatu hal yang baru dan bukan merupakan rutinitas yang dilakukan oleh masyarakat. Pada akhirnya keluaran hasil dari indikator ekonomi yang seharusnya dapat meningkatkan perekonomian lokal melalui potensi yang diangkat menjadi tema kampung yaitu hidroponik, tidak dapat memberikan manfaat ekonomi bagi masyarakat di Kampung Hidroponik.

Infrastruktur merupakan indikator terakhir yang dapat menentukan kelayakan tema yang diangkat dalam kampung tematik. Wilayah/kampung yang diangkat sebagai kampung tematik hendaknya merupakan wilayah yang kumuh, gersang dan tidak teratur. Harapannya jika wilayah/kampung tersebut diangkat menjadi kampung tematik maka terjadi peningkatan kualitas lingkungan di wilayah/kampung tersebut. Kampung Hidroponik yang juga merupakan perkampungan nelayan awalnya memiliki kondisi lingkungan yang kumuh, gersang dan tidak teratur. Melalui pelaksanaan kampung tematik perlahan kondisi infrastuktur mengalami peningkatan baik kualitas maupun kuantitas. Meskipun; terdapat peningkatan kualitas maupun kuantitas infrastruktur di Kampung Hidroponik, akan tetapi masyarakat beranggapan bahwa mereka belum merasakan manfaat dari peningkatan kualitas infrastruktur tersebut bagi kehidupan mereka. Hal tersebut juga diakibatkan oleh adanya proyek Kampung Bahari yang menyebabkan beberapa alat besar serta truk keluar masuk Kampung Hidroponik sehingga menyebabkan kerusakan pada beberapa infrastruktur yang telah dibangun pada pelaksanaan kampung tematik. Pembagian infrastruktur yang tidak merata pada tiap RT juga menjadi suatu permasalahan yang terjadi di Kampung Hidroponik. 


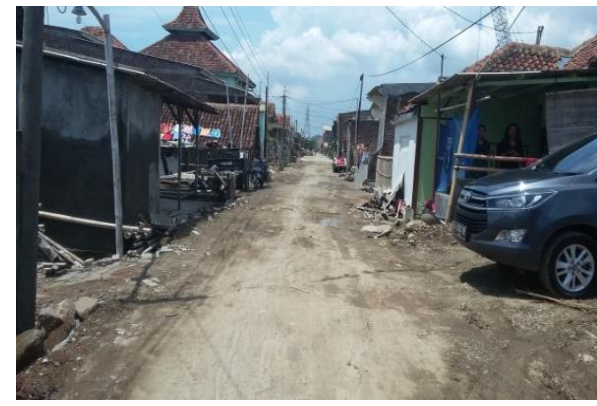

(a)

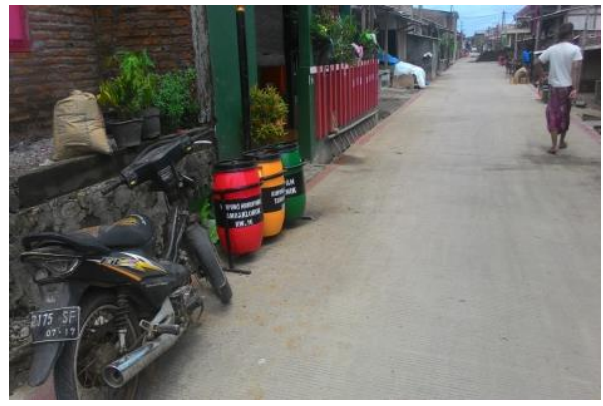

(b)

Sumber: Hasil Observasi, 2017

\section{Gambar 6. a) Kondisi Awal Sebelum Pelaksanaan Kampung Tematik; (b) Kondisi Saat Pelaksanaan Kampung Tematik}

Hidroponik yang diangkat sebagai tema kampung di Kelurahan Tanjung Mas seharusnya memiliki kesesuaian dengan beberapa poin yang terdapat di indikator sosial, ekonomi, maupun infrastuktur. Kemudian, jika poin-poin dalam indikator kesesuaian tema telah sesuai, maka tema yang telah ditentukan untuk suatu wilayah/kampung tersebut dapat dikatakan layak diangkat. Kelayakan tema yang diangkat pada suatu wilayah/kampung dapat menentukan indikator keluaran dan hasil yang diperoleh dari pelaksanaan kampung tematik. Faktanya, meskipun terdapat kesesuaian pada beberapa poin yang terdapat dalam indikator kelayakan tema akan tetapi hal tersebut belum dapat memberikan keluaran seperti yang diharapkan.

\section{Faktor-Faktor yang Mempengaruhi Tidak Berjalannya Kampung Hidroponik}

Pada implementasi Kampung Hidroponik, terdapat pula kegagalan yang terjadi dalam pelaksanaan konsep kampung tematik salah satunya yang terjadi di Kampung Hidroponik, Kelurahan Tanjung Mas. Beberapa faktor yang dikaji melalui analisis deskriptif kualitatif dengan mempertimbangkan proses pembentukan kampung tematik, kondisi fisik maupun masyarakat, maupun kelayakan tema yang diangkat pada suatu kampung. Perumusan faktor-faktor yang mempengaruhi tidak berjalannya kampung tematik juga tetap mempertimbangkan hasil penelitian, dokumen-dokumen pemerintah, dan referensi/teori terkait dengan pelaksanaan kampung tematik. Berdasarkan proses analisis data, maka didapatkan beberapa faktor yang menyebabkan tidak berjalannya pelaksanaan konsep kampung tematik khususnya yang terjadi di Kampung Hidroponik, Kelurahan Tanjung Mas. Faktor-faktor tersebut kemudian dikelompokkan dalam beberapa kategori dengan kategori yang didasarkan pada kesamaan gagasan yang terdapat antara satu faktor dengan lainnya. Hasil kategorisasi faktor-faktor yang menyebabkan tidak berjalannya konsep kampung tematik di Kampung Hidroponik, Kelurahan Tanjung Mas dapat dilihat pada Gambar 7. 


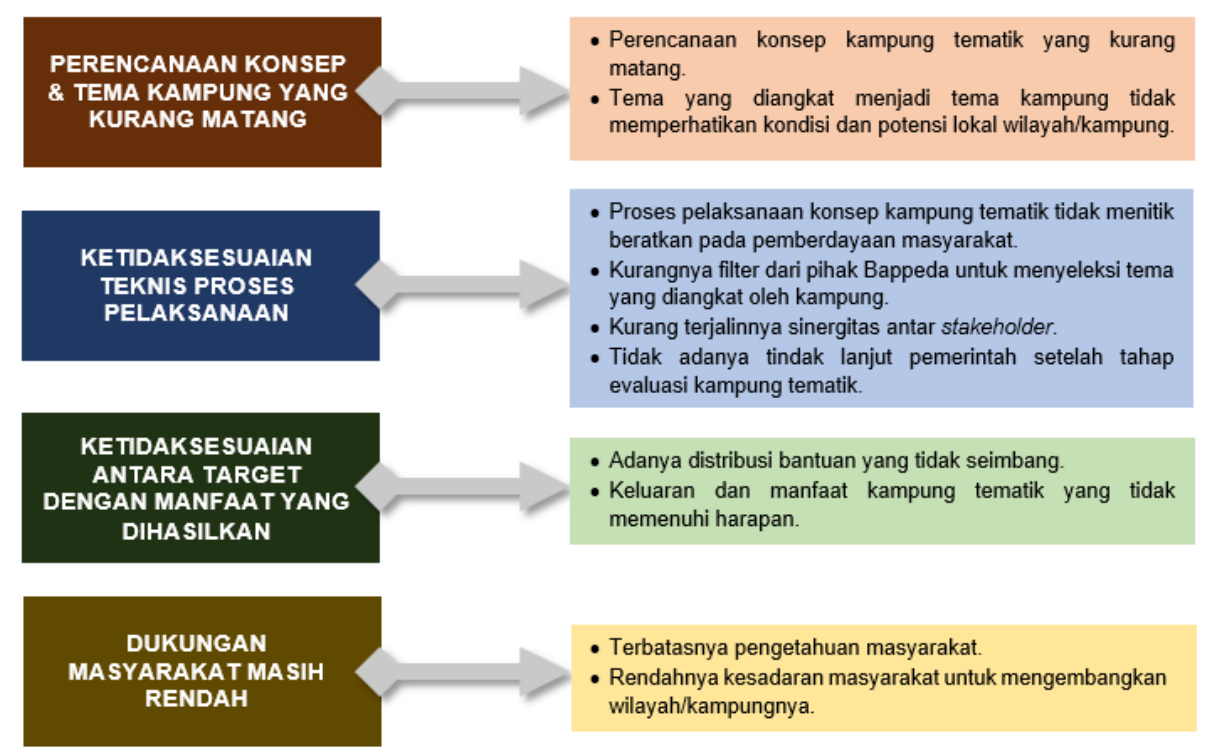

Sumber: Hasil Observasi, 2017

\section{Gambar 7. Faktor-Faktor yang Mempengaruhi Tidak Berjalannya Pelaksanaan Konsep Kampung Tematik di Kampung Hidroponik, Kelurahan Tanjung Mas}

Faktor-faktor yang mempengaruhi tidak berjalannya pelaksanaan konsep kampung tematik memiliki hubungan antara satu sama lain. Hubungan di antara faktor-faktor tersebut memperlihatkan adanya hubungan searah maupun hubungan timbal balik yang dapat dilihat pada Gambar 8.

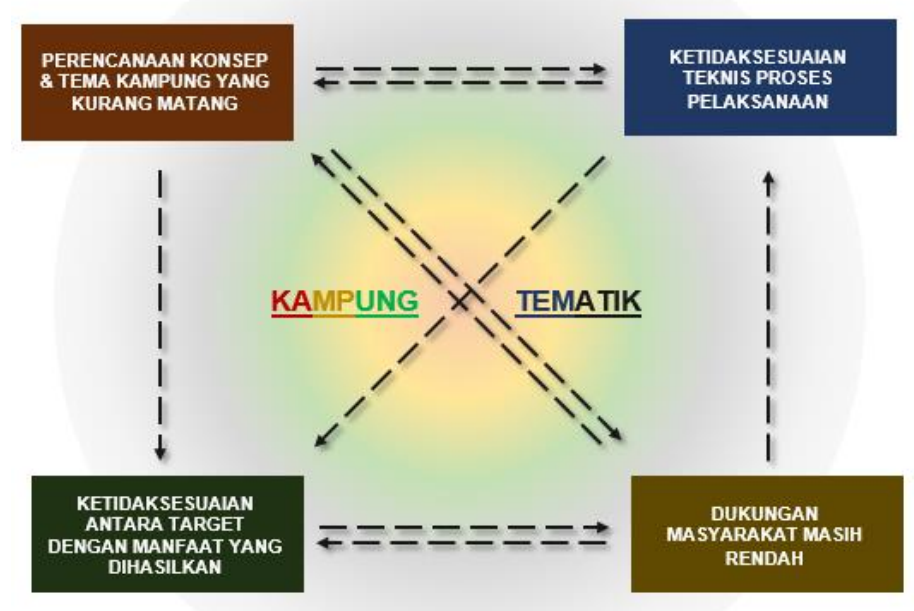

Keterangan:

$$
\leftarrow \rightarrow=\text { Hubungan Timbal Balik }
$$

\section{Gambar 8. Hubungan Faktor-Faktor yang Mempengaruhi Tidak Berjalannya Pelaksanaan Konsep Kampung Tematik di Kampung Hidroponik, Kelurahan TanjungMas}




\section{Kajian Pelaksanaan Konsep Kampung Tematik di Kampung Hidroponik...}

1. Perencanaan konsep dan tema kampung yang kurang matang

Identitas yang kemudian diangkat menjadi tema dari sebuah kampung dapat menghasilkan sebuah karakteristik yang unik dan meningkatkan nilai jual atas kampung mereka sendiri serta dapat menciptakan sumber pendapatan tambahan (Kłoczko-Gajewska, 2013). Namun, pada implementasinya terdapat beberapa faktor yang menghambat baik dari konsep maupun tema kampung seperti perencanaan konsep kampung yang kurang matang serta tema yang diangkat menjadi tema dalam suatu kampung tidak memperhatikan kondisi dan potensi lokal wilayah/kampung tersebut. Kurang matangnya perencanaan konsep maupun tema pada suatu kampung dapat saling mempengaruhi tingkat dukungan masyarakat serta teknis proses pelaksanaan konsep kampung tematik. Hal tersebut kemudian berimbas pada keluaran dan manfaat kampung tematik yang ternyata tidak dapat menanggulangi permasalahan kemiskinan serta meningkatkan kualitas hidup masyarakat.

2. Ketidaksesuaian teknis proses pelaksanaan

Pelaksanaan konsep kampung tematik di Kampung Hidroponik, Kelurahan Tanjung Mas dipengaruhi oleh ketidaksesuaian teknis proses pelaksanaan. Berdasarkan hasil analisis, terdapat 4 (empat) poin yang terkait dengan ketidaksesuaian teknis proses pelaksanaan suatu kampung di antaranya adalah proses pelaksanaan konsep kampung tematik tidak menitikberatkan pada pemberdayaan masyarakat, kurangnya filter dari pihak Bappeda untuk menyeleksi tema yang diangkat oleh kampung, kurang terjalinnya sinergitas antar pemangku kepentingan dan tidak adanya tindak lanjut pemerintah setelah tahap evaluasi kampung tematik. Ketidaksesuaian teknis proses pelaksanaan konsep kampung tematik berhubungan dengan penentuan tema kampung, hal tersebut karena salah satu tahapan yang harus dilakukan dalam pelaksanaan konsep kampung tematik salah satunya adalah menentukan tema yang akan diangkat menjadi karakteristik kampung tersebut. Konsep kampung tematik yang berbasis pada pemberdayaan masyarakat menjadikan dukungan masyarakat sebagai salah satu hal yang penting dan dapat mempengaruhi teknis proses pelaksanaan konsep kampung tematik. Apabila proses pelaksanaan konsep kampung tematik tidak berjalan sesuai dengan teknis yang telah ditetapkan, maka tentunya dapat berpengaruh pada kelayakan tema serta hasil dan manfaat dari pelaksanaan kampung tematik tersebut.

3. Manfaat yang dihasilkan tidak sesuai dengan target

Ketidaksesuaian target dengan manfaat yang dihasilkan turut mempengaruhi ketidakberhasilan pada pelaksanaan konsep kampung tematik di Kampung Hidroponik. Hasil monitoring dan evaluasi yang dilakukan oleh Bappeda pada Januari 2017 menunjukkan bahwa pelaksanaan Kampung Hidroponik diharapkan dapat meningkatkan ketahanan pangan masyarakat sekitarnya dengan standar kepemilikan paket hidroponik adalah 1 paket untuk $1 \mathrm{KK}$. Akan tetapi, bantuan paket hidroponik yang diberikan hanya berjumlah 20 paket. Hal tesebut sangat tidak sebanding dengan jumlah KK di Kampung Hidroponik yang mencapai $207 \mathrm{KK}$. Kondisi tersebut kemudian diperparah dengan tidak adanya dukungan masyarakat untuk kemudian melakukan budidaya hidroponik dengan melakukan replikasi dengan dana swadaya seperti halnya yang dilakukan pada Kampung Aquaponik di Kandri. Seperti yang dijelaskan sebelumnya, tema yang diangkat di Kampung Hidroponik juga tidak memiliki kesesuaian dengan kondisi maupun potensi wilayah/kampung tersebut. Hal ini juga kemudian turut mempengaruhi manfaat yang dihasilkan pada pelaksanaan konsep kampung tematik yang dilaksanakan di Kelurahan Tanjung Mas.

4. Dukungan masyarakat masih rendah

Petunjuk Teknis Pembentukan Kampung Tematik Kota Semarang Tahun 2017 menjelaskan bahwa pelaksanaan kampung tematik lebih menitikberatkan pada pemberdayaan masyarakat dalam perbaikan lingkungannya. Pemberdayaan masyarakat yang dimaksudkan agar masyarakat turut serta ikut dalam pembentukan kampungnya 
hingga masyarakat dapat mengalami peningkatan edukasi akan karakteristik lingkungan kampungnya. Berdasarkan hasil analisis, ditemukan bahwa meskipun proses pelaksanaan kampung tematik telah berupaya untuk meningkatkan pemberdayaan masyarakat dengan diadakannya pelatihan maupun sosialisasi, akan tetapi hal tersebut belum dapat meningkatkan pengetahuan dan kesadaran masyarakat untuk dapat mengembangkan wilayah/kampungnya. Dukungan masyarakat utamanya diperlukan pada tahap awal penentuan tema kampung karena pada proses tersebut, masyarakat diharapkan dapat memetakan kemudian mengidentifikasi potensi permasalahan lingkungannya. Menurut Kloczko-Gajewska (2014), kampung-kampung tematik memiliki kesesuaian dengan skema inovasi sosial berupa perubahan sikap sekelompok orang yang bergabung dalam jaringan kepentingan yang sejajar terkait dengan suatu cakrawala pengalaman kelompok mengarah pada cara baru yang lebih baik. Kampung tematik yang berhasil akan menghasilkan tindakan baru yang kemudian terus diimplementasikan pada beberapa jenis perbaikan yang sesuai. Pada kasus Kampung Hidroponik di Kelurahan Tanjung Mas, tindakan baru berupa pelaksanaan hidroponik tersebut tidak didukung oleh masyarakat, karena hal tersebut tidak sesuai dengan kondisi maupun potensi wilayahnya. Kondisi tersebut menjadikan Kampung Hidroponik yang awalnya dilakukan di Kelurahan Tanjung Mas semakin lama tidak berkembang dan bahkan ditinggalkan oleh masyarakat.

\section{Kesimpulan}

Kampung Hidroponik di Kelurahan Tanjung Mas tidak dapat melaksanakan konsep kampung tematik secara berkelanjutan di wilayahnya. Pelaksanaan konsep kampung tematik di Kampung Hidroponik dominan menggunakan pola pendekatan top-down dan kurang memperhatikan pada tahapan-tahapan perencanaan yang benar dengan pengangkatan tema kampung yang dilatarbelakangi oleh keinginan pihak kecamatan maupun kelurahan. Kampung Hidroponik belum melakukan penekanan pemberdayaan masyarakat yang berkelanjutan pada proses pelaksanaan konsep kampung di wilayahnya. Hal ini terjadi karena pelaksanaan konsep kampung tematik di tahun 2016 terjadi pada waktu yang sempit serta belum memiliki pedoman khusus. Oleh karena itu, Kampung Hidroponik pada proses pelaksanaannya tidak sesuai dengan Petunjuk Teknis Pembentukan Kampung Tematik yang baru dirumuskan Bappeda pada tahun 2017. Budidaya pertanian dengan menggunakan sistem hidroponik yang diangkat menjadi tema kampung tematik di Kelurahan Tanjung Mas tidak mengalami proses replikasi yang dapat menjadi salah satu penyokong keberlanjutan Kampung Hidroponik. Kegiatan budidaya hidroponik terus mengalami penurunan bahkan saat ini sudah tidak lagi dilakukan oleh masyarakat.

Kampung tematik ternyata belum dapat menjadi salah satu solusi permasalahan kemiskinan serta perbaikan kualitas lingkungan dengan pengelolaan potensi lokal wilayah yang berbasis pada pemberdayaan masyarakat. Terdapat berbagai kendala yang muncul dalam proses pelaksanaan konsep kampung tematik di Kampung Hidroponik, Kelurahan Tanjung Mas. Faktor-faktor yang menyebabkan tidak berjalannya konsep kampung tematik di Kampung Hidroponik Kelurahan Tanjung Mas antara lain ketidaksesuaian teknis proses pelaksanaan, perencanaan konsep dan tema kampung yang tidak sesuai target, manfaat yang dihasilkan tidak sesuai dengan target, dan dukungan masyarakat masih rendah. Berbagai faktor yang menyebabkan tidak berjalannya pelaksanaan konsep kampung tematik di Kampung Hidroponik menjadi suatu pembelajaran yang dapat diambil dalam usaha penanggulangan kemiskinan dan peningkatan kualitas lingkungan permukiman di Kota Semarang melalui kampung tematik. 


\section{Kajian Pelaksanaan Konsep Kampung Tematik di Kampung Hidroponik...}

\section{Daftar Pustaka}

Arbi, M. (2016). Kajian sebaran produksi dan perdagangan serta karakteristik konsumen sayuran hidroponik di Kota Palembang. Agriekonomika, 5(1), 54-63. Retrieved from http://journal.trunojoyo.ac.id/agriekonomika/article/view/1359.

Arikunto. (2010). Prosedurpenelitian: Suatu pendekatan praktek. Jakarta: Rineka Cipta.

Atkočiū nienè , V., \& Kaminaitè , G. (2017). The drivers of thematic village's development in strengthening their vitality. Management Theory and Studies for Rural Business and Infrastructure Development, 39(2), 139147. doi:10.15544/mts.2017.10.Vol.

Dimitra, S., \& Yuliastuti, N. (2012). Potensi kampung nelayan sebagai modal permukiman berkelanjutan di Tambaklorok, Kelurahan Tanjung Mas. Jurnal Teknik PWK, 1(1), 11-19. Retrieved from https://ejournal3.undip.ac.id/index.php/pwk/article/view/409.

Fosso, A., \& Kahane, R. (2013). Urban and peri urban horticulture in Namibia. Acta Horticulturae, 1007, 821827. doi:10.17660/ActaHortic.2013.1007.98.

Gernowo, R., Kusworo, A., \& Arifin, Z. (2013). Pengukuran variabilitas $\mathrm{CO}_{2}$ dan analisis dampak perubahan iklim (studi kasus: Semarang). Indonesian Journal of Applied Physics, 3(2), 144-149. Retrieved from https://jurnal.uns.ac.id/ijap/article/view/1248.

Heriwibowo, K., \& Budiana, N. S. (2014). Hidroponik sayuran untuk hobi dan bisnis. Jakarta: Penebar Swadaya.

Idziak, W., Majewski, J., \& Zmyś lony, P. (2015). Community participation in sustainable rural tourism experience creation: A long-term appraisal and lessons from a thematic villages project in Poland. Journal of Sustainable Tourism, 23(8-9), 1341-1362. doi:10.1080/09669582.2015.1019513.

Indarti, I. (2015). Pemberdayaan sumber daya masyarakat pesisir berbasis nelayan berkelanjutan di wilayah pesisir Semarang. Fokus Ekonomi, 191), 44-61. Retrieved from http:// ejournal.stiepena.ac.id/index.php/fe/article/download/72/69.

Kłoczko-Gajewska, A. (2013). General characteristics of thematic villages in Poland. Visegrad Journal on Bioeconomy and Sustainable Development, 2(2), 60-63. doi:10.2478/vjbsd-2013-0012.

Kloczko-Gajewska, A. (2014). Can we treat thematic villages as social innovations? Journal of Central European Green Innovation, 2(3), 49-59. Retrieved from https://ideas.repec.org/a/ags/hukrgr/188135.html.

Moleong, L. J. (2009). Metode penelitian kualitatif. Bandung: Remaja Rosdakarya.

Mursidik, E. M., Samsiyah, N., \& Rudyanto, H. E. (2015). Kemampuan berpikir kreatif dalam memecahkan masalah matematika open-ended ditinjau dari tingkat kemampuan matematika pada siswa sekolah dasar. Journal Pedagogia, 4(1), 23-33.

Mussadun, M., \& Nurpratiwi, P. (2016). Kajian penyebab kemiskinan masyarakat nelayan di Kampung Tambak Lorok. Journal of Regional and City Planning, 271), 49-67. doi:10.5614/jrcp.2016.27.1.5.

Rejekiningsih, T. W. (2011). Identifikasi faktor penyebab kemiskinan di Kota Semarang dari dimensi kultural. Jurnal Ekonomi Pembangunan, 12(1), 28-44. Retrieved from http://journals.ums.ac.id/index.php/JEP/article/view/203.

Sugiyono. (2015). Metode penelitian pendidikan, pendekatan kuantitatif, kualitatifdan R\&D. Bandung: Alfabeta.

Suradisastra, K. (2008). Strategi pemberdayaan kelembagaan petani. Forum Penelitian Agro Ekonomi, 26(2), 82-91. Retrieved from http:// ejurnal.litbang.pertanian.go.id/index.php/fae/article/view/3938. 